\begin{tabular}{|l|c|c|c|c|}
\hline $\begin{array}{l}\text { Cuadernos de Investigación Geográfica } \\
\text { Geographical Research Letters }\end{array}$ & 2017 & No $43(1)$ & pp. 209-232 & $\begin{array}{r}\text { ISSN 0211-6820 } \\
\text { eISSN 1697-9540 }\end{array}$ \\
\hline
\end{tabular}

\title{
AN UPDATED REVIEW ON RECENT TRENDS IN OBSERVATIONAL SURFACE ATMOSPHERIC VARIABLES AND THEIR EXTREMES OVER SPAIN
}

\author{
S.M. VICENTE-SERRANO ${ }^{*}$, E. RODRÍGUEZ-CAMINO ${ }^{2}$, \\ F. DOMÍNGUEZ-CASTRO ${ }^{1}$, A. EL KENAWY ${ }^{3}$, C. AZORÍN-MOLINA ${ }^{4}$

\begin{abstract}
${ }^{1}$ Instituto Pirenaico de Ecología, Consejo Superior de Investigaciones Científicas, Zaragoza, Spain.
${ }^{2}$ Agencia Estatal de Meteorología (AEMET), Madrid, Spain.

${ }^{3}$ Department of Geography, Mansoura University, Mansoura, Egypt.

${ }^{4}$ Regional Climate Group, Department of Earth Sciences, University of Gothenburg, Sweden.
\end{abstract}

\begin{abstract}
This article reviews the state-of-the-art findings on recent trends in observed atmospheric variables and their extremes in Spain. Our study screened peer-reviewed articles, published within the last decade, on recent climate variability in Spain, with a particular focus on a range of the essential atmospheric variables. The review focusses on the recent evolution of precipitation and air temperature, but also on other meteorological variables such as solar radiation, wind speed, surface humidity and evapotranspiration. While this review highlights results on changes in the mean state of climate in Spain, it also gives equal attention to findings on extreme weather events like rainstorms, heat waves and droughts. A detailed review of studies focusing on recent changes in the surface climate of Spain revealed some key findings. Studies demonstrate an overall increase of solar radiation since the 1980s. A similar behaviour was observed for surface air temperature since the 1960s, on the order of $+0.3^{\circ} \mathrm{C}$ decade ${ }^{-1}$, with rapid warming rates during summer. Different seasonal trend patterns of wind speed were noted over Spain, with declines in winter-spring and increases in summer-autumn. A remarkable decrease (-5\%) in relative humidity was observed from 1961 to 2011 . For precipitation, studies suggested a strong variability over both space and time, with a moderate decrease of the annual total precipitation. In accordance with changes in the mean conditions of climate, studies of extreme weather events stressed a notable warming in warm extremes, while changes in cold extremes were generally insignificant.
\end{abstract}

Revisión actualizada sobre las tendencias recientes de variables atmosféricas superficiales y sus extremos en España

RESUMEN. Este artículo revisa el actual estado de conocimiento sobre las tendencias recientes de diferentes variables atmosféricas y sus extremos en 
España. El estudio se centra en las aportaciones publicadas en revistas arbitradas por revisión entre pares y publicadas en la última década, especialmente en la evolución reciente de la precipitación y la temperatura del aire, pero también en la de otras variables meteorológicas como la radiación solar, velocidad de viento, humedad atmosférica y evapotranspiración. Pero además de incluir una revisión sobre los cambios en las condiciones medias de estas variables, también se muestran los más recientes resultados sobre la evolución de los eventos meteorológicos más extremos (por ejemplo, precipitaciones extremas, olas de calor o sequías). La revisión muestra algunos aspectos destacables. Los estudios realizados hasta la fecha demuestran un notable incremento de la radiación solar desde la década de 1980. Se observa un comportamiento similar para la temperatura del aire desde 1960, con un incremento de alrededor de $+0.3^{\circ} \mathrm{C}$ década ${ }^{-1}$, con un rápido calentamiento durante el verano. Se han identificado también diferencias estacionales en las tendencias de velocidad de viento, con descensos dominantes en invierno-primavera e incrementos en verano-otoño. Existe un notable descenso en los niveles de humedad relativa (-5\%) entre 1961 y 2011. Respecto a la precipitación, los estudios existentes sugieren una importante variabilidad en el tiempo y el espacio, con un moderado descenso en los valores de precipitación anual. Respecto a los cambios en los eventos más extremos de temperatura, se asiste a un notable incremento en la frecuencia de eventos cálidos, mientras que los cambios de los eventos más fríos resultan no significativos.

Key words: climate variability, precipitation, air temperature, solar radiation, wind speed, atmospheric evaporative demand, drought, Spain.

Palabras clave: variabilidad climática, precipitación, temperatura del aire, radiación solar, velocidad del viento, demanda atmosférica, sequía, España.

Received 11 November 2016

Accepted 10 January 2017

* Corresponding author: S.M. Vicente-Serrano, Instituto Pirenaico de Ecología, CSIC, Campus de Aula Dei, Apartado 13.034, 50080 Zaragoza, Spain. E-mail address: svicen@ipe.csic.es

\section{Introduction}

The climate of the Iberian Peninsula is mainly controlled by the geographic location of the peninsula, orography and the influences of different air masses (e.g. Atlantic, Mediterranean and sub-tropical) and circulation patterns (e.g. North Atlantic Oscillation, Mediterranean Oscillation). Accordingly, the Iberian climate is highly variable over space and time, with clear spatial and temporal differences in many climate variables (Ramis et al., 1997; De Castro et al., 2005; Vicente-Serrano and López-Moreno, 2006; Beguería et al., 2009; López-Moreno et al., 2010; El Kenawy et al., 2013). 
Earlier attempts to report changes in the climate of Spain in peer-reviewed journals occurred in the 1990s, with a particular focus on precipitation (García et al., 1995; Esteban-Parra et al., 1998; Rodriguez et al., 1999) and air temperature (Esteban-Parra et al., 1995). Bladé and Castro-Diez (2010) provided a comprehensive review on climate trends in the Iberian Peninsula during the instrumental period, with a special focus on precipitation and air temperature. According to this review, Spain witnessed a general air temperature increase during the $20^{\text {th }}$ century. This increase was more pronounced during the last decades of the $20^{\text {th }}$ century: a finding that is consistent with other regions of Europe. The review of Bladé and Castro-Diez (2010) indicated a strong spatial, seasonal and interannual variability of precipitation over Spain, with a general negative trend between 1960 and 2010. The tendency towards drying affected the frequency and intensity of extreme precipitation events, which tended to diminish during the same period. Nevertheless, Bladé and Castro-Diez (2010) did not include any updates on variability and changes of other essential atmospheric variables (e.g. relative humidity, wind speed, drought and atmospheric evaporative demand). These variables are relevant to the Spanish climate context, due to their environmental and socioeconomic impacts. Given their strong influence on evapotranspiration processes, changes in these variables may have impacts on the hydrological cycle and water resources (McVicar et al., 2012).

Chapter 2 of the IPCC2013 (Hartmann et al., 2013) focused on the observed atmospheric changes at the global scale, including a detailed review of current trends in air temperature and the hydrological cycle, especially large-scale changes in precipitation. This report also stressed the importance of analysing possible changes in air temperature and precipitation extreme events, as one of the main features of climate change processes, as well as changes in other atmospheric variables needed for understanding the complex characteristics of climate change (e.g. evapotranspiration, solar radiation, wind speed, cloud coverage, surface humidity). For example, Wild et al. (2013) concluded that a global assessment of brightening is necessary, as it gives indications on recent changes in solar radiation. Similarly, Vautard et al. (2010) suggested an investigation of changes in stilling, as an indicator of changes in near-surface wind speed, at the global scale. More recently, Willet et al. (2014) showed a recent decrease in relative humidity over large regions of the world.

Although there are several studies that have analysed changes in the chemical composition of the atmosphere (e.g., Fernández-Fernández et al., 2011), the overriding aim of this article is to review literature on recent changes in atmospheric variables over Spain. In particular, we revised peer-reviewed articles on changes in solar radiation, near-surface wind speed, surface humidity and evapotranspiration. With respect to surface air temperature and precipitation, we restricted our review only to those studies published after Bladé and Castro-Díez (2010).

\section{Changes in solar radiation}

Together with the anthropogenic alteration of the atmospheric composition as a consequence of higher greenhouse gasses concentrations, incoming solar radiation that reaches the surface is another relevant forcing that may affect the magnitude of warming 
processes at the global scale (Wild et al., 2013). Hartmann et al. (2013) documented a general decrease of surface solar radiation at the global scale from the 1950s to 1980s, a period known as "global dimming", followed by a partial recovery from the 1980s onward ("brightening period"). A number of studies support this behaviour in Europe, and updates on surface solar radiation data since 2000 suggest a continuation of the brightening. A detailed assessment of changes in the surface solar radiation in Spain is difficult since available solar radiation series from radiometers are generally short and very sparse (Sánchez-Lorenzo et al., 2013). For this reason, long-term variability and changes in surface solar radiation have been usually analysed by means of sunshine duration series - obtained by means of Campbell-Stokes recorderspanning the period from the beginning of the $20^{\text {th }}$ century. Sanchez-Lorenzo et al. (2009) analysed changes in sunshine duration and cloud cover in Spain between 1964 and 2004, suggesting a strong correlation between both variables. Nevertheless, they found some discrepancy from 1960s to 1980s: a behaviour that concurs with the "global dimming period" reported by the IPCC (2013). Over this period, the decrease in sunshine duration was not associated with cloud coverage increase. On the contrary, from the early 1980s to 2004, an upward trend or "brightening" was recorded across Spain seasonally and annually. The observed pattern from the 1980s agrees with the few available observations of solar radiation. Sánchez-Lorenzo et al. (2013) developed a homogeneous dataset of surface solar radiation in Spain, demonstrating a significant upward trend between 1985 and 2010 on the order of $3.9 \mathrm{Wm}^{-2} \mathrm{decade}^{-1}$. Similar significant increases were observed in the mean seasonal series, with the highest rate of increase during summer $\left(6.5 \mathrm{Wm}^{-2}\right.$ decade $\left.^{-1}\right)$. These results confirm the "brightening" phenomenon in Spain over the last decades, a pattern that was recently confirmed by Perdigao et al. (2016) using reanalysis datasets.

To account for the possible mechanisms responsible for brightening, Mateos et al. (2013) analysed data of shortwave radiation from 13 locations over Spain, with the aim of determining the radiative effects of clouds and aerosols in the period 1985-2010. They found a significant decrease of the radiative effects of clouds and aerosols. More recently, Mateos et al. (2014) quantified the contribution of each of clouds and aerosols to "brightening" processes in Spain, indicating that clouds are the key factor responsible for explaining "brightening" trends, as they explain approximately $75 \%$ of the solar radiation changes, while a possible reduction of aerosol concentrations explains $25 \%$ of "brightening" trends.

\section{Air temperature variability and change}

\subsection{Mean air temperature}

Although radiative forcing caused by more intense surface solar radiation can contribute to the observed air temperature trends, there is a strong confidence that thermal forcing, driven by changes in the chemical composition of the atmosphere, is the main driver of air temperature variability and change (Hartmann et al., 2013). Based on a range of global air temperature datasets, the IPCC2013 reported a general agreement on the sign (i.e. positive) of changes in air temperature since the mid of the $19^{\text {th }}$ century, 
though being more accelerated since the 1970s. A similar temporal pattern was already confirmed by Bladé and Castro-Díez (2010) for Spain, albeit with an enhanced air temperature increase in recent decades $\left(0.48^{\circ} \mathrm{C}\right.$ decade $\left.^{-1}\right)$, which is $50 \%$ higher than the trend observed in the northern hemisphere.

The most recent studies analysing air temperature trends in Spain gave new insights on warming rates over the past decade. Some articles employed high density databases (e.g. Brunet et al., 2006; Hofstra et al., 2009). The use of these dense databases is advantageous in the sense that the temporal variability of air temperature over Spain is highly variable, and air temperature trends can thus be better expressed by using regional series for different territories, both for maximum and minimum air temperatures (Peña-Angulo et al., 2015).

For peninsular Spain, some studies have analysed changes in air temperature using a highly dense network of observatories. One example is Del Río et al. (2011) who analysed the evolution of mean air temperature using 473 meteorological stations between 1961 and 2006. They showed dominant positive trends, mainly in spring and summer months, suggesting an annual increase between 0.1 and $0.2^{\circ} \mathrm{C}$ decade $^{-1}$, which was statistically significant in the entire peninsular Spain. Later, Del Río et al. (2012) employed the same dataset to analyse the evolution of maximum and minimum air temperatures for the same period. They found an identical rate of increase $\left(0.3^{\circ} \mathrm{C}\right.$ decade $\left.^{-1}\right)$ for maximum and minimum temperatures, particularly in summer and spring months. The average of increase in maximum temperature was $0.37^{\circ} \mathrm{C}$ and $0.43^{\circ} \mathrm{C}$ decade ${ }^{-1}$ during summer and spring, respectively. For minimum temperature, the warming rate was $0.34^{\circ} \mathrm{C}$ (summer) and $0.41^{\circ} \mathrm{C}$ decade $^{-1}$ (spring). Recently, Gonzalez-Hidalgo et al. (2015) developed a dense dataset, composed of 1358 homogeneous temperature series from 1951 to 2010, over peninsular Spain. They demonstrated that maximum temperature has risen in late winter/ early spring and summer, while minimum temperature has increased in summer, spring and autumn, especially in Spain southern regions. Moreover, they showed that trends in the daily temperature range had a clear north-south gradient during summer, with positive trends in the north and negative trends in the south. The overall signal in maximum temperature showed a positive trend over more than $75 \%$ of land, and the strongest signal was detected in June, in which $87 \%$ of land exhibited a statistically significant positive trend. Also, changes in maximum temperature showed a different spatial structure with reference to minimum temperature. In particular, rapid changes in minimum temperature were identified in the Mediterranean area (central-southern areas and eastern coastland) in March,April, May, September and October; while significant positive trends extend over the whole continental Spain, except the north-west northern plateau, in June, July and August.

Overall, results of changes in air temperature across Spain agree on a strong temperature increase affecting the whole territory. Nonetheless, recent studies also suggest that the warming rate has noticeably decreased in the past two decades in comparison to the strong increase recorded in the preceding decades. This temporal pattern has been identified at the global scale and called "warming hiatus" (Fyfe et al., 2013), requiring different mechanisms to explain this phenomenon (Trenberth, 2015). In Spain, although the recent findings of the long-term temperature evolution have shown a strong temperature increase since 1850 (Sigró et al., 2015), recent studies also suggest a slowdown of temperature trends in the past 
two decades. In particular, temperatures in the past two decades would show a lower rate of temperature increase than that shown between 1970 and 1995 (González-Hidalgo et al., 2016).

At a more detailed scale, several studies were more specific to assess changes in air temperature over particular regions in Spain. For example, El Kenawy et al. (2012) employed a long-term (1920-2006) dataset of 19 homogenized observatories and a denser dataset of 126 observatories for the period 1960-2006 to assess changes in air temperature over northeastern Spain. They identified an average increase of $0.11{ }^{\circ} \mathrm{C}$ decade $^{-1}$ between 1920 and 2006 , which was more pronounced for minimum $\left(0.14^{\circ} \mathrm{C}\right.$ decade $\left.^{-1}\right)$ than for maximum air temperature $\left(0.08^{\circ} \mathrm{C}\right.$ decade $\left.^{-1}\right)$. Seasonally, summer exhibited the largest warming trend $\left(0.22^{\circ} \mathrm{C}\right.$ decade $\left.^{-1}\right)$. They also showed a clear spatial gradient in the warming processes, as coastal areas warmed at higher rates compared with mainland areas. In Catalonia, Martínez et al. (2010) indicated higher air temperature increase during the warm season (JJA). In accordance, Homar et al. (2009) found a very strong summer warming trend in the Balearic Islands from 1976 to $2006\left(+0.73^{\circ} \mathrm{C}\right.$ decade $\left.^{-1}\right)$. The magnitude of change was similar to that found in the Canary Islands for the period 1981-2010, varying from 0.40 to $0.46^{\circ} \mathrm{C}$ decade $^{-1}$ (Cropper and Hanna, 2014). In their assessment of air temperature changes in the island of Tenerife, Martín et al. (2012) found a strong spatial contrast between high mountains, which showed a higher increase than coastal areas, where the effect of the Atlantic Ocean modulated the general air temperature rise. In the Valencia region, Miro et al. (2015) found a remarkable warming tendency in mountain areas, with less pronounced warming in valleys and coastal plains, particularly for minimum air temperature. In contrast, the tendency for increasing maximum temperature was more generalized for the period 1948-2011.

Martínez et al. (2010) analysed trends of temperature in Catalonia, indicating a clear breakpoint in the temperature increase around 1995 and no significant warming trends from 1995 to 2004, mainly recorded for minimum temperature. Recently, GonzálezHidalgo et al. (2016) suggested that the warming rate in both maximum and minimum temperatures was more pronounced over the Spanish mainland between 1970 and 1990, followed by a decrease in the intensity of warming until the present. Furthermore, they found that the slowdown of warming rates in maximum temperature has been higher than in minimum temperature for the last three decades, suggesting that recent annual warming is mainly driven by changes in minimum temperature than those of maximum temperature. According to González-Hidalgo et al. (2016), there is a general warming from 1970 and a recent warming hiatus from the mid-1990s to the present. Nevertheless, although this hiatus is more specific to the cold season (DJF), temperature has also shown some increase in summer and spring during the 1990s and 2000s, mainly caused by changes in minimum temperature. Again, this pattern suggests that current warming processes are more controlled by night-time temperature than by daytime temperature. Overall, an assessment of the links between El Niño phenomenon and the Spanish temperature in 2015 and 2016 can confirm the hypothesis of Kosaka and Xie (2013), in which the hiatus phenomenon is related to the anomalous period of cold temperature in the Eastern Pacific region. Thus, recent analyses pointed out that the internal climate variability is important to explain the slowdown of air temperature trends as well as the robust warming projections despite the recent hiatus (England et al., 2015; Wehner and Easterling, 2016). 


\subsection{Changes in daily temperature extremes}

Although the IPCC2013 report suggested a slowdown in the frequency of warm nights and warm days since the mid1990s (Hartmann et al., 2013), Beniston (2015) showed that extreme maximum temperatures in Europe exhibit sharp increases since 2000, despite a slowdown in the rise of mean temperatures. Thus, Barriopedro et al. (2011) showed a high frequency of record temperature events in Europe in the last decade (2000-2010), with no precedents in the last two centuries. This pattern is confirmed also in Spain in recent studies that indicate a strong increase in the frequency and magnitude of high temperatures in the last decade.

A number of recent studies have analysed changes in daily temperature extremes over Spain, using a range of percentile-based indices. In general, Spain exhibited a decrease in the frequency of winter cold events and a general increase in the frequency of summer warm events and heat waves (e.g. Garcia-Herrera et al., 2005; El Kenawy et al., 2011). A range of regional studies confirm this pattern over Spain, including: central (Labajo et al., 2012; Labajo et al., 2014) and northeastern Spain (El Kenawy et al., 2011, 2013a and 2013b; López-Moreno et al., 2014). Rodríguez-Puebla et al. (2010) analysed changes in warm days and cold nights over the whole Iberian Peninsula for the period 1950-2006, using a threshold of the $90^{\text {th }}$ percentile of daily maximum temperature distribution to define warm days, and the $10^{\text {th }}$ percentile of daily minimum temperature distribution to define cold nights. They indicated that warm days increased by $1.1 \%$ of decade $^{-1}$ on average, while cold nights exhibited a decrease on the order of $-1.3 \%$ decade $^{-1}$. This study also defined two subperiods: 1950-1979 and 1980-2006, with remarkable changes in the frequency distribution of cold nights and warm days. Nevertheless, Acero et al. (2014) analysed summer extreme temperatures over Spain using non-urban station data and the extreme value theory, suggesting that temperature extremes are increasing, but not as much as the mean temperature. Also, recent studies by Fernández-Montes and Rodrigo (2012) and Fernandez-Montes et al. (2013) employed data from 1929 to 2005 and indices of daily temperature extremes to give evidences on a significant decreasing trend $\left(-0.6\right.$ days decade $\left.{ }^{-1}\right)$ in the frequency of frost days for coastal stations, especially from 1965 onwards. These investigations also reveal significant increasing trends from 1980 onwards, particularly for tropical nights in southeast (3.8 days decade $\left.{ }^{-1}\right)$, and summer days in southern stations (2.3 days decade $\left.{ }^{-1}\right)$. Thus, the observed warming has impacts on the definition of the warm season in Spain.

Peña-Ortiz et al. (2015) analysed changes in the onset, end and length of summer season using temperature thresholds. They found an increase in the length of summer season, mainly between 1979 and 2012. This increase ranges between 5 and 12 days decade $^{-1}$, and has been mainly driven by an earlier onset in June.

The increase in the frequency of warm temperature extremes was continuous during the past two decades. Sánchez-Lorenzo et al. (2012) confirmed that the average frequency of tropical nights showed a continuous increase since the beginning of the 1970 s, with the most extreme values recorded during the 2000 s, independently of the region of Spain. A similar temporal pattern was observed over the Iberian Peninsula (Fernández-Montes and Rodrigo, 2012), the central plateau (Labajo et al., 2014) and northeastern Spain (El Kenawy et al., 2012). 


\section{Changes in surface winds}

Given the lack of dense networks of surface wind, the IPCC2013 stressed that the confidence in surface wind trends is low. Nevertheless, a weakening of seasonal and annual mean wind speed, referred to as "global stilling", has been reported over many continental regions from 1960s onwards, with direct energetic and hydrological implications (Vautard et al., 2010). Since wind speed is one of the main variables controlling the atmospheric evaporative demand, their declining trends could noticeably affect the complete hydrological cycle (McVicar et al., 2012b). Numerous studies have analysed the spatial and temporal variability of wind speed over Spain. Lorente-Plazas et al. (2015) showed a strong spatial variability of the direction as well as the magnitude of wind speed over the whole Spain. Nevertheless, albeit the dense dataset of wind stations $(>500)$, the temporal coverage of these series was very short (2002-2006). Thus, it has not been possible to assess long-term trends in wind characteristics, making results on wind speed trends highly uncertain. In addition, assessing changes in wind speed is also impacted by the measurement procedure. Recently, Azorín-Molina et al. (2017) showed significant differences in the magnitude of wind speed over Spain, when considering synoptictime intervals and 24 hours run measurements. Nevertheless, this study also concluded that there are no differences in wind speed trends from 1961 to 2011, regardless of the measurement procedure. Azorín-Molina et al. (2014) have also used 67 monthly average wind speed series in Spain and Portugal from 1961 and 2011, showing a generally slight downward trend for the period 1961-2011 (-0.016 $\mathrm{ms}^{-1}$ decade $\left.{ }^{-1}\right)$. However, they have found seasonal differences, with a declining trend in winter and spring and an increasing trend in summer and autumn. Over Spain, wind "stilling" affected almost $77.8 \%$ of the stations in winter and $66.7 \%$ in spring. Nonetheless, roughly $40 \%$ of the declining trends were statistically significant. On the contrary, increasing tendency appeared in $51.9 \%$ of the stations in summer and $57.4 \%$ in autumn, from which only $40 \%$ of stations showed statistically significant positive trends Nevertheless, changes in the magnitude of wind speed did not show a clear spatial structure, either at the seasonal or the annual scales. Azorin-Molina et al. (2016) analysed trends of daily peak wind gusts in Spain between 1961 and 2014 by means of the frequency (90th percentile) and the magnitude of the wind speed maxima of daily peak wind gusts. Results revealed less frequent and declining daily peak wind gusts during the cold half (November-April) of the year, compared to more frequent and increasing wind gusts during the warm half (May-October) of the year.

\section{Changes in surface humidity}

Possible changes in surface humidity can be important, as this variable affects the quantity of water vapour that a parcel of air can store and thus the atmospheric evaporative demand. IPCC2013 indicates the likely widespread increase of specific humidity from 1973 to 2012 at the global scale, suggesting that relative humidity would remain constant according to Clausius-Clapeyron relationship, given the unlimited available moisture at the global scale. Nevertheless, new observations suggest that this principle could not drive the evolution of surface relative and specific humidity in large regions of the world, mainly in semiarid regions (Simmons et al., 2008; Willet et al., 2014; Sherwood and Fu, 2014). 
In Spain there are few studies analysing recent atmospheric humidity trends. Mattar et al. (2011) used radiosonde data to analyse changes in column integrated water vapour from 1973 to 2003, suggesting statistically significant negative trends $(<-0.04 \mathrm{~mm}$ year $\left.^{-1} ; \mathrm{p}<0.05\right)$ in the south of the Iberian Peninsula. More recently, Moratiel et al. (2016) assessed changes in wet-bulb and dew point temperature across Spain at different temporal scales between 1981 and 2010. These measurements give indirect assessments of humidity changes. Moratiel et al. (2016) showed strongly different trends derived from air temperature and wet-bulb temperature data, suggesting indirectly noticeable changes in the relative air humidity during the study period.

Vicente-Serrano et al. (2014) calculated surface relative and specific humidity and assessed their trends between 1961 and 2011. Results showed a large decrease in relative humidity over mainland Spain from 1961 to 2011, which was more pronounced in spring and summer (-1.02\% and $-1.56 \%$ decade $^{-1}$, respectively). On average, the decrease was on the order of $-5.1 \%$ at the annual scale between 1961 and 2011. In contrast, there was no overall change in the specific humidity in this period, except in spring that exhibited an increase. Spatially, while the decrease in relative humidity affected the entire country, changes in specific humidity were less homogeneous. These results suggest an increase in the water holding capacity of the atmosphere, as a consequence of warming during recent decades. Nonetheless, this increase was not accompanied by an increase in surface water vapour content, probably because the supply of water vapour from the main terrestrial land/oceanic areas has been constrained, as suggested by Sherwood and Fu (2014).

\section{Changes in the hydrological cycle: precipitation and evapotranspiration}

The Spain report on Climate and Ocean: Variability, Predictability and Change (CLIVAR) project in 2010 made a detailed review of precipitation changes in Spain over the past decades (Bladé and Castro-Díez, 2010), stressing the high number of studies on this issue. However, these studies provided different results, as a consequence of the different homogenization tests applied to precipitation time series, varying study periods and the spatial density of rain gauges. In particular, Bladé and Castro-Díez (2010) indicated a general reduction in the total precipitation over the period 1960-2008, which affected most of the Iberian Peninsula. Nevertheless, they concluded that the magnitude of changes differed considerably, as a function of the database used and the study period. In the same context, there are a number of recent studies that have analysed precipitation trends in Spain, but with various methodological approaches, as some studies analysed long term magnitude (i.e. seasonal and annual), while others assessed changes at more fine (i.e. daily and sub-daily) scales.

\subsection{Monthly, seasonal and annual precipitation changes}

Considering a long-term perspective, Camuffo et al. (2013) analysed precipitation changes from two observatories in Spain (Barcelona and San Fernando), with long (>200 yrs) instrumental records. Both stations showed that the precipitation decrease between the 1960s and 2005 in spring and summer is unprecedented since the beginning 
of the 19th century. Different regional studies analysed precipitation trends covering different periods, but in general they recorded dominant negative trends during the past decades, including:, Altava-Ortiz et al. (2011) for three meteorological stations in the Mediterranean, De Luis et al. (2009) in the Mediterranean Iberian Peninsula, FernándezMontes and Rodrigo (2015) in southeast Spain, Homar et al. (2010) in the Balearic Islands, Guerreiro et al. (2014) in the basins of the Douro, Tagus and Guadiana rivers and Ruiz-Sinoga et al. (2011) in southern Spain. Other studies did not show significant trends in precipitation at the seasonal and annual scales, such as Cropper and Hanna (2014) for the Canary Islands.

There are also studies that have analysed precipitation trends in Spain, but using dense network of meteorological rain gauges. One example is González-Hidalgo et al. (2011) who employed 2670 complete and homogeneous series for the period 1946-2005. They demonstrated that monthly precipitation trends show high monthly variability, with coherent spatial trend patterns in March, June (both with a general and significant negative trend) and October (general positive trends). More localized trend patterns were noted in July, February and April. Their results suggest that these local patterns are mainly controlled by topography. Del Río et al. (2011b) also analysed the spatial distribution of rainfall trends (1961-2006) using a dense database of 553 weather stations. This study revealed a decrease in rainfall in more than $28 \%$ of the Spanish territory during summer and winter. Although regional patterns of rainfall changes are complex, regional series over the whole Spain showed a precipitation decrease in winter and at the annual scale (Rodríguez-Puebla and Nieto, 2010). Vicente-Serrano et al. (2014) created an average precipitation series using 50 series over the Iberian Peninsula between 1961 and 2011, suggesting a statistically significant decrease on the order of $-18.7 \mathrm{~mm} \mathrm{decade}^{-1}$, which was linked directly to the generalized streamflow decrease in the Iberian Peninsula since the 1950s (Lorenzo-Lacruz et al., 2012).

In addition to changes in precipitation magnitude, some studies also analysed possible changes in the temporal variability of precipitation and in precipitation regimes. Some studies showed an increase in the interannual precipitation variability. Over the Mediterranean region of Spain, De Luis et al. (2009) found an increase of precipitation variability in winter $(+23.5 \%)$ and summer $(+11.4 \%)$ and a decrease in autumn $(-14.9 \%)$ and spring $(-16.8 \%)$, with a global mean value of $+7.8 \%$. GarcíaBarrón et al. (2011) analysed the evolution of annual rainfall irregularity in the southwest of the Iberian Peninsula, showing a progressive increase towards stronger interannual fluctuations of precipitation. In contrast, Guerreiro et al. (2014) did not find clear and generalized patterns toward higher or lower interannual variability in monthly precipitation series in central Spain. Therefore, more studies are still needed to increase confidence in assessments of changes in the temporal variability of precipitation over Spain.

In the same context, De Luis et al. (2011) analysed precipitation concentration changes in Spain (1946-2005), indicating an increase in precipitation concentration across most of the Iberian Peninsula, mainly driven by the increase in precipitation concentration during the wet season (October-March). Also, González-Hidalgo (2010) showed a 
general redistribution of precipitation throughout the year, with a reduction in the length of the wet season (due to the negative trend in March) and a concentration of precipitation at the beginning of the wet season in October. These results concur with García-Barrón et al. (2013) who found rapid changes in the most intense rainy periods during autumn and a consequent decrease in precipitation during spring across southwest Iberian Peninsula. Likewise, De Luis et al. (2010) analysed possible changes in traditionally described seasonal rainfall regimes in Spain during 1946-2005. They found that the percentage of territory in which winter constitutes the dominant precipitation season decreased from $51.1 \%$ to $42.7 \%$ of the total study area. While this area decreased in spring from $36.1 \%$ to $15.1 \%$, it increased notably in autumn from $10.8 \%$ (restricted to the Mediterranean coast) to $41.4 \%$ of the territory. Overall, this study demonstrated that the wet season was shortened, inducing a concentration of the water input at the onset of the hydrological year (i.e. September-October).

\subsection{Changes in daily extreme precipitation}

Given their impacts on natural environments (e.g. water resources, biodiversity, hydrology, etc.) and human communities (e.g. energy, health, agriculture, etc.), recent studies focused not only on changes in the total precipitation magnitude, temporal variability and seasonality in Spain, but they also accounted for the frequency, intensity and duration of daily precipitation records. Bladé and Castro-Díez (2010) showed that daily precipitation intensity might have been reduced in the past 50 years, inducing an increase in the frequency of days recording low precipitation and a decrease in the frequency of intense precipitation events. Recent studies confirmed this pattern, although the strong spatial variability of intense precipitation events and the difficulties of analysing daily rainfall series make it difficult to assess whether precipitation intensity has noticeably changed in Spain.

With respect to precipitation frequency, Acero et al. (2012) analysed multi-day (1 to 7 days) rainfall trends in the Iberian Peninsula for the period 1958-2004. They found significant negative trends for a great part of the Iberian Peninsula in winter. In contrast, significant positive trends were observed over small areas in the southeast. According to this study, spring also showed negative trends for a great part of the Iberian Peninsula. Different studies analysed trends in daily precipitation indices at regional and national scales. For example, López-Moreno et al. (2010) assessed changes in daily precipitation indices for the northeastern Iberian Peninsula for the period 1955-2006, indicating a general decrease in the number of rainy days and precipitation intensity, and an increase in the duration of dry spells. Heavy rainfall events generally decreased in the west of the region during winter and in the east during autumn, concluding that these areas are more prone to hazards related to extreme rainfall. Valencia et al. (2012) also analysed changes in extreme rainfall indices for the Ebro River Basin using 14 meteorological stations from 1957 to 2002, showing a weakly but significant reduction of the extreme values in areas of high precipitation and near to the Mediterranean Sea. Homar et al. (2009) showed a different pattern for the Balearic Islands between 1950 and 2006, given that light $(<4 \mathrm{~mm})$ and heavy $(>64 \mathrm{~mm})$ daily precipitation contributed 
largely to the annual total precipitation, while the share from moderate-heavy (16-32 $\mathrm{mm}$ ) precipitation decreased. Turco and Llasat (2011) investigated changes in indices of daily precipitation extremes over Catalonia, confirming that only the consecutive dry day index at annual scale showed a locally coherent spatial trend pattern, with around $30 \%$ of Catalonia experiencing an increase of 2-3 days decade de $^{-1}$.

At the national level, there are a number of studies that analysed trends in high precipitation events. For example, Gallego et al. (2011) analysed trends in frequency indices of daily precipitation during the last century (1903-2003), using data from 27 stations in Portugal and Spain. They found that the total number of rainy days and that of light $(\geq 0.2$ and $<0.25 \mathrm{~mm})$ rainfall increased at many observatories over the Iberian Peninsula for all seasons. Nevertheless, some studies suggest a concentration of precipitation in a fewer number of days. Cortesi et al. (2012) assessed the statistical structure of daily precipitation over Europe from 1971 to 2010 using the daily precipitation concentration index (CI), suggesting significant positive trends in most of observatories south of Spain and along the Mediterranean coasts. More recently, Merino et al. (2016) defined regions that exposed to extreme precipitation hazards over the Iberian Peninsula and assessed trends of extreme precipitation index from 1960 to 2011, based on the $99^{\text {th }}$ percentile of daily precipitation distribution.

The application of extreme value theory to assess trends in the most severe precipitation events is difficult given the irregularity of these extreme events and the common short length of their series. Albeit these limitations, some recent studies analysed this issue in Spain. A representative example is Acero et al. (2011) who used a peaks-over-threshold approach to study trends in extreme rainfall over the Iberian Peninsula. They indicated a high variability of extreme events over the Mediterranean coastline. The calculation of the trends for a 2-yr return period yielded a large proportion of negative trends for the considered seasons: $58 \%$ for winter, $63 \%$ for spring, and $69 \%$ for autumn. Nevertheless, the parametric approach also revealed an increase in the area with positive trends for a 20 -yr return level, relative to a 2-yr return period. This feature could give indications on certain increase of intense precipitation events. Extreme value theory was also used by Beguería et al. (2011) to assess trends in the intensity and magnitude of extreme precipitation events using a set of 64 daily rainfall series in northeastern Spain from 1930 to 2006. Statistical significance was achieved only in less than $5 \%$ of the stations at the annual scale, suggesting no evidence of a generalized trend in extreme precipitation in the region. Also, Rodrigo (2010) analysed changes in the probability of daily precipitation observed from 1951 to 2002 in the Iberian Peninsula using a simple statistical model of daily precipitation based on the gamma distribution. This study showed that the trend of the probability of daily rainfall less than the 5th percentile is positive, mainly to the north and to the south of the Iberian Peninsula. In contrast, the probability of daily rainfall higher than the 95 th percentile is negative, which would suggest a decrease of rainfall intensity during this period.

\subsection{Snow precipitation}

There are very few studies that analysed trends in snow precipitation, which is highly variable in time and space (Navarro-Serrano and López-Moreno, 2017). Overall, results 
are inconclusive and seem to be highly affected by the period of analysis. Pons et al. (2010) analysed snow trends in northern Spain using daily snow occurrence data from a network of 33 stations. They showed a significant decreasing trend in the annual number of snow days since the mid-1970s to 2001 , with a reduction of about $-50 \%$. These changes were of similar magnitude for both low- and highly-elevated stations during winter and spring. In contrast, Buisan et al. (2015) investigated the spatial and temporal variability of winter snow in the western and central Spanish Pyrenees over the period 1961-2013, concluding that the definition of the study period can markedly influence the observed trends. In particular, they showed a statistically significant decrease in the number of snow days for the period 1971-2000, while trends were statistically insignificant for the periods 1961-2013 and 1980-2010.

\subsection{The atmospheric evaporative demand}

In addition to precipitation, evapotranspiration is a very relevant atmospheric variable to the hydrological cycle. However, it is necessary to distinguish between the actual evapotranspiration (ETa), which corresponds to the transferred water to the atmosphere in the form of vapor, and the potential evapotranspiration (PET), which corresponds to total water that would evaporate assuming that water supply from land is unlimited (see further details in Katerji and Rana, 2011). PET is difficult to determine since it depends on land conditions and vegetation types. For this reason, the concept of reference evapotranspiration (ETo) is alternatively used, which refers to a reference surface and it can be compared across different climate regimes and land surface conditions (Allen et al., 1998). ETa is even more difficult to measure and there are no long term observations of this variable. As a supplementary source of data, land surface models and remote sensing images are used to quantify spatio-temporal variability of this variable, but with caution given their high uncertainty, particularly at the global scale (Hartmann et al., 2013). The long term evolution of the Atmospheric Evaporative Demand (AED) has been usually assessed by means of evaporation pans. Nevertheless, IPCC2013 indicates only a medium confidence in the assessment of the AED changes at the global scale.

There are recent studies that have analysed AED trends in Spain using evaporation observations and robust physical models, based on the ETo Penman-Monteith scheme (e.g. Azorín-Molina et al., 2015; Vicente-Serrano et al., 2016). This method is based on different meteorological variables (e.g. wind speed, solar radiation, relative humidity and air temperature), providing accurate quantification of the AED (Allen et al., 1998).

Espadafor et al. (2011) analysed ETo trends from 1960 to 2005 at eight stations in southern Spain, suggesting a general increase, mainly in summer months. More recently, Vicente-Serrano et al. (2014b) analysed temporal variability and trends in ETo over the whole Spain from 1961 to 2011, based on quality controlled and homogeneous series of various meteorological variables. On average, they found a strong increase (24.4 mm decade ${ }^{-1}$ ) in the magnitude of ETo at the annual scale across Spain, with the main increase in summer $\left(12 \mathrm{~mm}\right.$ decade $\left.^{-1}\right)$. Using the same dataset, Vicente-Serrano et al. (2014c) analysed the sensitivity of ETo to the observed changes in a set of meteorological 
parameters (e.g. relative humidity, air temperature, wind speed, etc). They found that the aerodynamic component is more important in determining ETo, with respect to the radiative component. They also found that ETo trends were mainly explained by the decrease in relative humidity and the increase in maximum temperature since the 1960s, particularly during summer months. Sánchez-Lorenzo et al. (2014) developed, for the first time, an evaporation dataset for Spain based on long-term series of Piché atmometer and pan measurement records. Both the mean annual Piché and pan series showed evaporative increases over Spain during the study period (1985-2011). Furthermore, using the annual Piché records since the 1960s, an evaporation decline was detected from the 1960s to the mid-1980s, which resulted in a non-significant trend over the entire period 1961-2011, with the exception of summer season. More recently, AzorínMolina et al. (2015) analysed the spatio-temporal evolution of evaporation observations from Piché atmometer and pan evaporimeters, and compared both measurements with evaporation estimates obtained by four physical models. They found that annual and seasonal trends of evaporation estimates showed a statistically significant increase for the period 1961-2011. This temporal evolution did not agree with long-term Piché evaporation trends; e.g. a discontinuity was found around the 1980s. They stressed that radiative and aerodynamic driving factors suggest that this discontinuity, and the observed evaporation trends across Spain, could be associated with the abrupt increase in air temperature observed at the beginning of the 1980s.

\subsection{Droughts}

IPCC2013 indicated low to medium confidence in assessments of drought trends at the global scale, given the few objective drought metrics, lack of direct observations, geographical inconsistencies of trends and dependencies of inferred trends on the chosen index and period (Hartmann et al., 2013). Moreover, determining drought trends under the current warming scenario is not an easy task, given the influence of different factors (e.g. precipitation and atmospheric evaporative demand) (VicenteSerrano, 2016). In Spain, there are objective metrics that suggest increased drought severity, based on a dense and long database of streamflow records (Lorenzo-Lacruz et al., 2013). Using precipitation data, Vicente-Serrano (2013) analysed the evolution of droughts in Spain for the period 1910-2011, and stressed strong spatial variability. This study indicated that some regions showed a decrease in drought severity (e.g. Galicia and the southeast), whereas other regions showed increased severity (e.g. southwest, Catalonia and the central Ebro basin) (Coll et al., 2016). Thus, south Spain showed a large increase in the duration and magnitude of the drought events (Peña-Gallardo et al., 2016). Using a climate aridity index in Extremadura, Moral et al. (2016) found a general increase of land aridity annually, in summer and spring between 1951 and 2000. Lorenzo-Lacruz and Moran-Tejeda (2016) analysed droughts in the Balearic Islands between 1974 and 2014 based on the Standardized Precipitation Index, showing a strong temporal variability, but with no clear trends in this region. In the same context, Vicente-Serrano et al. (2014d) showed evidence on increasing drought severity, as driven mainly by the temperature rise in the Iberian Peninsula. They confirmed that drought severity increased in the past five decades, as a consequence of greater 
atmospheric evaporative demand resulting from temperature rise. They also stressed that recent positive trends in the atmospheric water demand had a direct influence on the temporal evolution of streamflow, particularly during the warm season, in which higher evapotranspiration rates are recorded.

\section{Conclusions}

This article reviewed the international scientific literature published within the last ten years on atmospheric trends in Spain, with a particular emphasis on the new released findings after the review of Bladé and Castro-Díez (2010). There are a number of studies dealing with trends in the different surface climate variables, including solar radiation, humidity, wind speed, air temperature and precipitation. While some studies covered the whole Spain, others focused on particular regions in the country. Although recent climate trends are determined by the used datasets and mostly the selected periods for analysis, it is possible to draw some concluding remarks for the different variables, which are illustrated in Figure 1:

i) There is a strong solar radiation increase from the $1980 \mathrm{~s}$, which has been caused by cloud cover trends ( $75 \%$ of solar radiation changes) and aerosols concentrations ( $25 \%$ of changes).

ii) Temperatures showed strong increases (around $+0.3^{\circ} \mathrm{C}$ decade $^{-1}$ ) since the 1960 s, which were stronger in summer months. A slowdown of the mean temperature increase was recorded from the end of the 1990s, mainly driven by the evolution of maximum temperature. Nevertheless, the frequency of extreme warm temperature events (heat waves) noticeably increased from 2000.

iii) There are no noticeable changes in surface wind speed. A slight downward trend has been recorded but it is not statistically significant. Moreover, a different seasonal trend pattern of wind speed has been identified, with declines in winterspring and increases in summer-autumn.

iv) Strong decrease in relative humidity was recorded (-5\% between 1961 and 2011). In contrast, no changes in absolute humidity were identified.

v) There is a strong spatial and seasonal variability in precipitation trends, although average annual precipitation over Spain showed a moderate decrease in the past five decades. Studies on temporal trends in variability revealed different results and a change in the precipitation regime was recorded, indicating a trend toward shortened wet season and a higher percentage of autumn precipitation in the annual total.

vi) There is a strong uncertainty on trends in extreme precipitation events at daily scales, although most studies suggest an increase in the days recording low precipitation.

vii) There is no robust evidence on trends in snow occurrence, as the selection of the study period can noticeably influence the observed trends. 


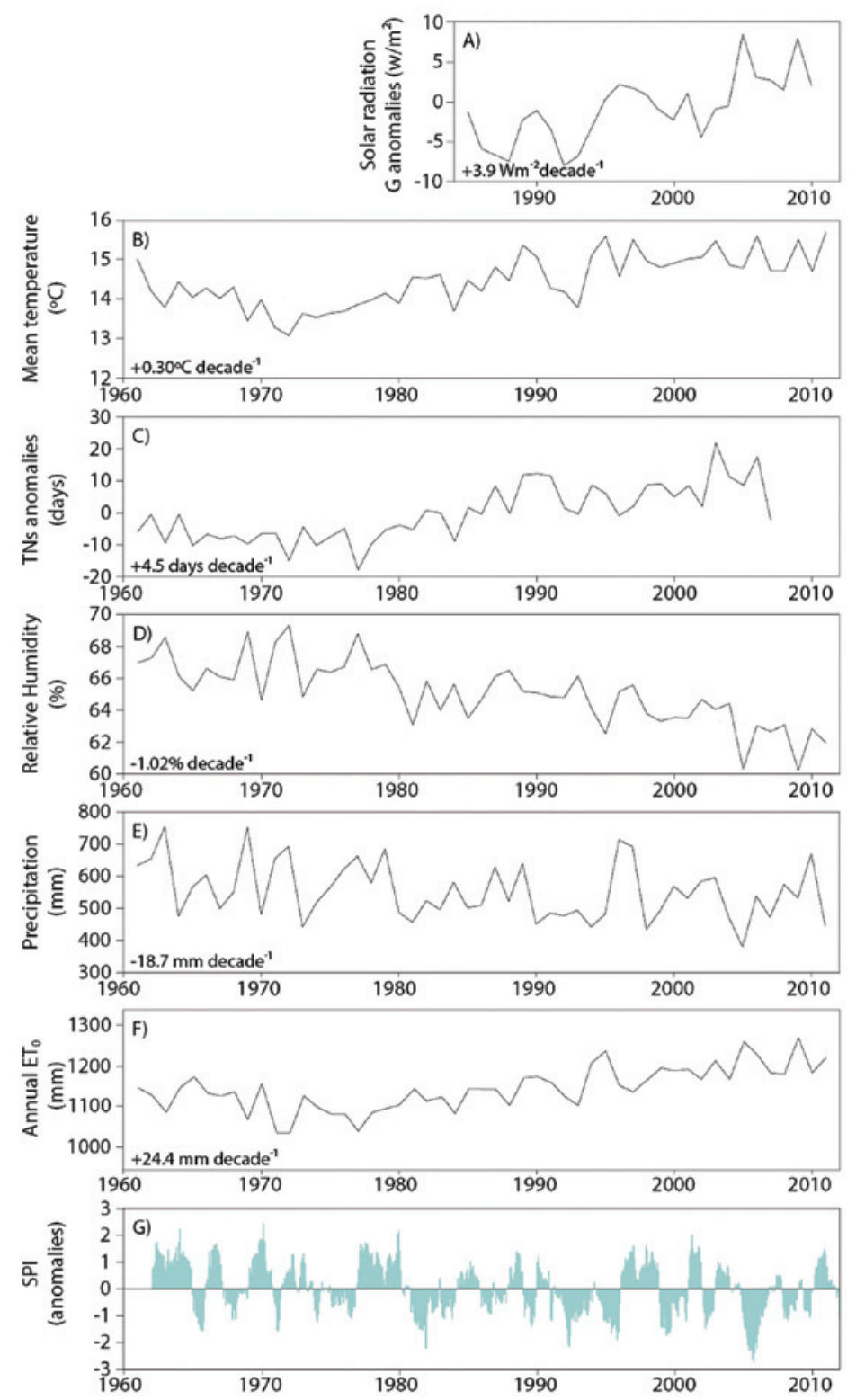

Figure 1. Meteorological variables for Iberian Peninsula analysed in the text (A) Mean annual $G$ series expressed as anomalies from the 1991-2010 mean (modified from Sánchez-Lorenzo et al., 2013).(B) Evolution of annual mean temperature (1961-2011) (modified from Vicente-Serrano et al., 2014) (C) JJAS temporal evolution of Tropical nights (Sánchez-Lorenzo et al., 2012) (D) Evolution of annual RH (1961-2011) (modified from Vicente-Serrano et al., 2014) (E) Evolution of annual precipitation) (modified from Vicente-Serrano et al., 2014) (F) Evolution of annual ET $T_{0}$ computed by PenmanMonteith method (modified from Vicente-Serrano et al., 2014b) (G) Monthly evolution of standardized precipitation index (SPI) (modified from Vicente-Serrano et al., 2014d). 
viii) The atmospheric evaporative demand increased in the past five decades $(+24.4$ mm decade ${ }^{-1}$ ), mainly in summer months. This has been mainly driven by the decrease in relative humidity, besides the temperature increase.

ix) Drought frequency and severity increased in most of Spain, not only due to precipitation decrease, but also as a consequence of the increase in atmospheric evaporative demand.

Trends observed in some of the variables are in agreement with observations in some neighbour Mediterranean areas (Hartman et al., 2013). Nevertheless, although this is mostly valid for precipitation and temperature, it is difficult to establish robust comparisons for other variables such as wind speed, humidity or solar radiation, as there are very few studies on recent trends in these atmospheric variables over other Mediterranean regions. Overall, the recent climate trends observed for Spain clearly suggest a warmer and drier scenario in comparison to past decades. This finding is compatible with observations in other Mediterranean areas, where there is a tendency toward a climate scenario characterized by lower water availability (García-Ruiz et al., 2011) and the occurrence of more severe and frequent drought events (Hoerling et al., 2012).

\section{Acknowledgements}

This work was supported by the research project PCIN-2015-220, CGL201452135-C03-01, Red de variabilidad y cambio climático RECLIM (CGL2014-517221REDT) financed by the Spanish Commission of Science and Technology and FEDER, "LIFE12 ENV/ES/000536-Demonstration and validation of innovative methodology for regional climate change adaptation in the Mediterranean area (LIFE MEDACC)" financed by the LIFE programme of the European Commission, and IMDROFLOOD financed by the Water Works 2014 co-funded call of the European Commission.

\section{References}

Acero, F.J., García, J.A., Gallego, M.C. 2011. Peaks-over-threshold study of trends in extreme rainfall over the Iberian Peninsula. Journal of Climate 24, 1089-1105. http://doi. org/10.1175/2010JCLI3627.1.

Acero, F.J., Gallego, M.C., García, J.A. 2012. Multi-day rainfall trends over the Iberian Peninsula. Theoretical and Applied Climatology 108, 411-423. http://doi.org/10.1007/s00704-0110534-5.

Acero, F.J., García, J.A., Gallego, M.C., Parey, S., Dacunha-Castelle, D. 2014. Trends in summer extreme temperatures over the Iberian Peninsula using nonurban station data. Journal of Geophysical Research Atmospheres 119, 39-53. http://doi.org/10.1002/2013JD020590.

Allen, R.G., Pereira, L.S., Raes, D. 1998. Crop evapotranspiration-guidelines for computing crop water requirements. FAO Irrigation and drainage, paper 56. Food and Agricultural Organization, Rome.

Altava-Ortiz, V., Llasat, M.C., Ferrari, E., Atencia, A., Sirangelo, B. 2011. Monthly rainfall changes in Central and Western Mediterranean basins, at the end of the 20th and beginning of the 21st centuries. International Journal of Climatology 31, 1943-1958. http://doi. org/10.1002/joc.2204. 
Azorín-Molina, C., Vicente-Serrano, S.M., McVicar, T.R., Jerez, S., Sánchez-Lorenzo, A., López-Moreno, J.-I., Revuelto, J., Trigo, R.M., López-Bustins, J.A., Espírito-Santo, F. 2014. Homogenization and assessment of observed near-surface wind speed trends over Spain and Portugal, 1961-2011. Journal of Climate 27, 3692-3712. http://doi.org/10.1175/ JCLI-D-13-00652.1.

Azorín-Molina, C., Vicente-Serrano, S.M., McVicar, T.R., Revuelto, J., Jerez, S., López-Moreno, J.I. 2017. Assessing the impact of measurement time interval when calculating wind speed means and trends under the stilling phenomenon. International Journal of Climatology 37, 480-492. http://doi.org/ 10.1002/joc.4720.

Azorín-Molina, C., Guijarro, J.A., McVicar, T.R., Vicente-Serrano, S.M., Chen, D., Jerez, S., Espírito-Santo, F. 2016. Trends of daily peak wind gusts in Spain and Portugal, 19612014. Journal of Geophysical Research: Atmospheres 121, 1059-1078. http://doi. org/10.1002/2015JD024485.

Azorín-Molina, C., Vicente-Serrano, S.M., Sánchez-Lorenzo, A., McVicar, T.R., MoránTejeda, E., Revuelto, J., El Kenawy, A., Martín-Hernández, N., Tomas-Burguera, M. 2015. Atmospheric evaporative demand observations, estimates and driving factors in Spain (1961-2011). Journal of Hydrology 523, 262-277. http://doi.org/10.1016/j. jhydrol.2015.01.046.

Barriopedro, D., Fischer, E.M., Luterbacher, J., Trigo, R.M., García-Herrera, R. 2011. The hot summer of 2010: Redrawing the temperature record map of Europe. Science 332, 220-224. http://doi.org/10.1126/science.1201224.

Beguería, S., Angulo-Martínez, M., Vicente-Serrano, S.M., López-Moreno, J.I., El-Kenawy, A. 2011. Assessing trends in extreme precipitation events intensity and magnitude using nonstationary peaks-over-threshold analysis: A case study in northeast Spain from 1930 to 2006. International Journal of Climatology 31, 2102-2114. http://doi.org/10.1002/joc.2218.

Beniston, M. 2015. Ratios of record high to record low temperatures in Europe exhibit sharp increases since 2000 despite a slowdown in the rise of mean temperatures. Climatic Change 129, 225-237. http://doi.org/10.1007/s10584-015-1325-2.

Bladé, I., Castro Díez, Y. 2010. Tendencias atmosféricas en la Península Ibérica durante el periodo instrumental en el contexto de la variabilidad natural, En: Clima en España: pasado, presente y futuro (F.F. Pérez, R. Boscolo, Eds.) Ministerio de Ciencia e Innovación y Ministerio de Medio Ambiente y Medio Rural y Marino, Madrid, pp. 25-42.

Brunet, M., Saldie, O., Jones, P., Sigro, J., Aguilar, E., Moberg, A., Lister, D., Walther, A., López, D., Almarza, C. 2006. The development of a new dataset of Spanish daily adjusted temperature series SDATS 1850-2003. International Journal of Climatology 25, 1777-1802. http://doi.org/10.1002/joc.1338.

Buisan, S.T., Saz, M.A., López-Moreno, J.I. 2015. Spatial and temporal variability of winter snow and precipitation days in the western and central Spanish Pyrenees. International Journal of Climatology 35, 259-274. http://doi.org/10.1002/joc.3978.

Camuffo, D., Bertolin, C., Diodato, N., Cocheo, C., Barriendos, M., Dominguez-Castro, F., Garnier, E., Alcoforado, M.J., Nunes, M.F. 2013. Western Mediterranean precipitation over the last 300 years from instrumental observations. Climatic Change 117, 85-101. http://doi. org/10.1007/s10584-012-0539-9.

Coll, J.R., Aguilar, E., Prohom, M., Sigró, J. 2016. Long-term drought variability and trends in Barcelona (1787-2014). Cuadernos de Investigación Geográfica 42, 29-48. http://doi. org/10.18172/cig. 2927.

Cortesi, N., González-Hidalgo, J.C., Brunetti, M., Martín-Vide, J. 2012. Daily precipitation concentration across Europe 1971-2010. Natural Hazards and Earth System Science 12, 2799-2810. http://doi.org/10.5194/nhess-12-2799-2012. 
Cropper, T.E., Hanna, E. 2014. An analysis of the climate of Macaronesia, 1865-2012. International Journal of Climatology 34, 604-622. http://doi.org/10.1002/joc.3710.

De Castro, M.J., Martín-Vide, M., Brunet, M. 2005. The climate of Spain: Past, present and scenarios for the 21 st century. Publicaciones Ministerio de Medio Ambiente, pp. 207-218.

De Luis, M., González-Hidalgo, J.C., Longares, L.A., Štepánek, P. 2009. Seasonal precipitation trends in the Mediterranean Iberian Peninsula in second half of 20th century. International Journal of Climatology 29, 1312-1323. http://doi.org/10.1002/joc.1778.

De Luis, M., Brunetti, M., González-Hidalgo, J.C., Longares, L.A., Martín-Vide, J. 2010. Changes in seasonal precipitation in the Iberian Peninsula during 1946-2005. Global and Planetary Change 74, 27-33. http://doi.org/ 10.1016/j.gloplacha.2010.06.006.

De Luis, M., González-Hidalgo, J.C., Brunetti, M.,Longares,L.A.2011.Precipitation concentration changes in Spain 1946-2005. Natural Hazards and Earth System Science 11, 1259-1265. http://doi.org/10.5194/nhess-11-1259-2011.

Del Río, S., Herrero, L., Pinto-Gomes, C., Penas, A. 2011. Spatial analysis of mean temperature trends in Spain over the period 1961-2006. Global and Planetary Change 78, 65-75. http:// doi.org/10.1016/j.gloplacha.2011.05.012.

Del Río, S., Herrero, L., Fraile, R., Penas, A. 2011b Spatial distribution of recent rainfall trends in Spain (1961-2006). International Journal of Climatology 31, 656-667. http://doi. org/10.1002/joc.2111.

Del Río, S., Cano-Ortiz, A., Herrero, L., Penas, A. 2012. Recent trends in mean maximum and minimum air temperatures over Spain (1961-2006). Theoretical and Applied Climatology 109, 605-626. http://doi.org/10.1007/s00704-012-0593-2.

El Kenawy, A., López-Moreno, J.I., Vicente-Serrano, S.M. 2011. Recent trends in daily temperature extremes over northeastern Spain (1960-2006). Natural Hazards and Earth System Science 11, 2583-2603. http://doi.org/10.5194/nhess-11-2583-2011.

El Kenawy, A., López-Moreno, J.I., Vicente-Serrano, S.M. 2012. Trend and variability of surface air temperature in northeastern Spain (1920-2006): Linkage to atmospheric circulation. Atmospheric Research 106, 159-180. http://doi.org/10.1016/j.atmosres.2011.12.006.

El Kenawy, A., López-Moreno, J.I., Vicente-Serrano, S.M. 2013. Summer temperature extremes in northeastern Spain: Spatial regionalization and links to atmospheric circulation (19602006). Theoretical and Applied Climatology 113, 387-405. http://doi.org/10.1007/s00704012-0797-5.

El Kenawy, A., López-Moreno, J.I., Brunsell, N.A., Vicente-Serrano, S.M. 2013b. Anomalously severe cold nights and warm days in northeastern Spain: Their spatial variability, driving forces and future projections. Global and Planetary Change 101, 12-32. http://doi. org/10.1016/j.gloplacha.2012.11.011.

England, M.H., Kajtar, J.B., Maher, N. 2015. Robust warming projections despite the recent hiatus. Nature Climate Change 5, 394-396. http://doi.org/10.1038/nclimate2575.

Espadafor, M., Lorite, I.J., Gavilán, P., Berengena, J. 2011. An analysis of the tendency of reference evapotranspiration estimates and other climate variables during the last 45 years in Southern Spain. Agricultural Water Management 98, 1045-1061. http://doi.org/10.1016/j. agwat.2011.01.015.

Esteban-Parra, M.J., Rodrigo, F.S., Castro-Diez, Y. 1995. Temperature trends and change points in the northern Spanish Plateau during the last 100 years. International Journal of Climatology 15, 1031-1042. http://doi.org/10.1002/joc.3370150909.

Esteban-Parra, M.J., Rodrigo, F.S., Castro-Diez, Y. 1998. Spatial and temporal patterns of precipitation in Spain for the period 1880-1992. International Journal of Climatology 18, 1557-1574. http://doi.org/10.1002/(SICI)1097-0088(19981130)18:14<1557::AIDJOC328>3.0.CO;2-J. 
Fernández-Fernández, M.I., Gallego, M.C., García, J.A., Acero, F.J. 2011 . A study of surface ozone variability over the Iberian Peninsula during the last fifty years. Atmospheric Environment 45, 1946-1959. http://doi.org/10.1016/j.atmosenv.2011.01.027.

Fernández-Montes, S., Rodrigo, F.S. 2012. Trends in seasonal indices of daily temperature extremes in the Iberian Peninsula, 1929-2005. International Journal of Climatology 32, 2320-2332. http://doi.org/10.1002/joc.3399.

Fernández-Montes, S., Rodrigo, F.S., Seubert, S., Sousa, P.M. 2013. Spring and summer extreme temperatures in Iberia during last century in relation to circulation types. Atmospheric Research 127, 154-177. http://doi.org/10.1016/j.atmosres.2012.07.013.

Fernández-Montes, S., Rodrigo, F.S. 2015. Trends in surface air temperatures, precipitation and combined indices in the southeastern Iberian Peninsula (1970-2007). Climate Research 63, 43-60. http://doi.org/10.3354/cr01287.

Gallego, M.C., Trigo, R.M., Vaquero, J.M., Brunet, M., García, J.A., Sigró, J., Valente, M.A. 2011. Trends in frequency indices of daily precipitation over the Iberian Peninsula during the last century. Journal of Geophysical Research Atmospheres 116, D02109, 28. http://doi. org/10.1029/2010JD014255.

García, J.A., Marroquín, A., Garrido, J., Mateos, V.L. 1995. Analysis of daily rainfall processes in lower Extremadura (Spain) and homogenization of the data. Theoretical and Applied Climatology 51, 75-87. http://doi.org/ 10.1007/BF00865542.

Garcia-Herrera, R., Díaz, J., Trigo, R. M., Hernández, E. 2005. Extreme summer temperatures in Iberia: health impacts and associated synoptic conditions. Annals Geophysicae 23, 239-251. http://doi.org/10.5194/angeo-23-239-2005.

García-Barrón, L., Aguilar, M., Sousa, A. 2011. Evolution of annual rainfall irregularity in the southwest of the Iberian Peninsula. Theoretical and Applied Climatology 103, 13-26. http:// doi.org/10.1007/s00704-010-0280-0.

García-Barrón, L., Morales, J., Sousa, A. 2013. Characterisation of the intra-annual rainfall and its evolution (1837-2010) in the southwest of the Iberian Peninsula. Theoretical and Applied Climatology 114, 445-457. http://doi.org/10.1007/s00704-013-0855-7.

García-Ruiz, J.M., López-Moreno, J.I., Vicente-Serrano, S.M., Lasanta, T., Beguería, S. 2011. Mediterranean water resources in a global change scenario. Earth-Science Reviews 105, 121139. http://doi.org/10.1016/j.earscirev.2011.01.006.

González-Hidalgo, J.C., Brunetti, M., De Luis, M. 2010. Precipitation trends in Spanish Hydrological Divisions, 1946-2005. Climate Research 43, 215-228. http://doi.org/10.3354/cr00937.

González-Hidalgo, J.C., Brunetti, M., de Luis, M. 2011. A new tool for monthly precipitation analysis in Spain: MOPREDAS database (monthly precipitation trends December 1945-November 2005. International Journal of Climatology 31, 715-731. http://doi. org/10.1002/joc.2115.

González-Hidalgo, J.C., Peña-Angulo, D., Brunetti, M., Cortesi, N. 2015. MOTEDAS: a new monthly temperature database of Spanish continental land and the temperature trend between 1951-2010. International Journal of Climatology 35, 4444-4463. http://doi.org/10.1002/joc.4298.

González-Hidalgo, J.C., Peña-Angulo, D., Brunetti, M., Cortesi, N. 2016. Recent trend in temperature evolution in Spanish mainland (1951-2010): from warming to hiatus. International Journal of Climatology 36, 2405-2416. http://doi.org/10.1002/joc.4519.

Guerreiro, S.B., Kilsby, C.G., Serinaldi, F. 2014. Analysis of time variation of rainfall in transnational basins in Iberia: Abrupt changes or trends? International Journal of Climatology 34, 114-133. http://doi.org/10.1002/joc.3669.

Hartmann, D.L., Klein Tank, A.M., Rusticucci, M. 2013. Observations: Atmosphere and Surface. In: Climate Change 2013: The Physical Science Basis. Contribution of Working Group I to the Fifth Assessment Report of the Intergovernmental Panel on Climate Change (T.F. 
Stocker, D. Qin, G.K. Plattner, M. Tignor, S.K. Allen, J. Boschung, A. Nauels, Y. Xia, V. Bex, P.M. Midgley eds.). Cambridge University Press, Cambridge, United Kingdom and New York, NY, USA.

Hoerling, M., Eischeid, J., Perlwitz, J., Quan, X., Zhang, T., Pegion, P. 2012. On the increased frequency of Mediterranean drought. Journal of Climate 25, 2146-2161. http://doi. org/10.1175/JCLI-D-11-00296.1.

Hofstra, N., Haylock, M., New, M., Jones, P. 2009. Testing E-OBS European high-resolution gridded dataset of daily precipitation and surface temperature. Journal of Geophysical Research- Atmospheres 114, D21101. http://doi.org/10.1029/2009JD011799.

Homar, V., Ramis, C., Romero, R., Alonso, S. 2009. Recent trends in temperature and precipitation over the Balearic Islands (Spain). Climatic Change 98, 199-211. http://doi.org/10.1007/ s10584-009-9664-5.

Katerji, N., Rana, G. 2011. Crop reference evapotranspiration: a discussion of the concept, analysis of the process and validation. Water Resources Management 25, 1581-1600. http:// doi.org/10.1007/s11269-010-9762-1.

Kosaka, Y., Xie, S.P. 2013. Recent global-warming hiatus tied to equatorial Pacific surface cooling. Nature 501, 403-407. http://doi.org/10.1038/nature12534.

Labajo, J.L., Labajo, A.L., Egido, M., Martín, Q., Morales, C., Ortega, M.T. 2012. Analysis of the maximum daily temperature evolution on the Spanish Central Plateau. Atmosfera 25, 235-252.

Labajo, A.L., Egido, M., Martín, Q., Labajo, J., Labajo, J.L.2014. Definition and temporal evolution of the heat and cold waves over the Spanish Central Plateau from 1961 to 2010. Atmosfera 27, 273-286.

López-Moreno, J.I., Vicente-Serrano, S.M., Angulo-Martínez, M., Beguería, S., Kenawy, A. 2010. Trends in daily precipitation on the northeastern Iberian Peninsula, 1955-2006. International Journal of Climatology 30, 1026-1041. http://doi.org/10.1002/joc.1945.

López-Moreno, J.I., El-Kenawy, A., Revuelto, J., Azorín-Molina, C., Morán-Tejeda, E., LorenzoLacruz, J., Zabalza, J., Vicente-Serrano, S.M. 2014. Observed trends and future projections for winter warm events in the Ebro basin, northeast Iberian Peninsula. International Journal of Climatology 34, 49-60. http://doi.org/10.1002/joc.3665.

Lorente-Plazas, R., Montávez, J.P., Jiménez, P.A., Jerez, S., Gómez-Navarro, J.J., García-Valero, J.A., Jimenez-Guerrero, P. 2015. Characterization of surface winds over the Iberian Peninsula. International Journal of Climatology 35, 1007-1026. http://doi.org/10.1002/joc.4034.

Lorenzo-Lacruz, J., Vicente-Serrano, S.M., López-Moreno, J.I., Morán-Tejeda, E., Zabalza, J. 2012. Recent trends in Iberian streamflows (1945-2005). Journal of Hydrology 414-415, 463-475. http://doi.org/10.1016/j.jhydrol.2011.11.023.

Lorenzo-Lacruz, J., Morán-Tejeda, E., Vicente-Serrano, S.M., López-Moreno, J.I. 2013. Streamflow droughts in the Iberian Peninsula between 1945 and 2005: spatial and temporal patterns. Hydrology and Earth Systems Science 17, 119-134. http://doi.org/10.5194/hess-17119-2013.

Lorenzo-Lacruz, J., Morán-Tejeda, E. 2016. Spatio-temporal patterns of meteorological droughts in the Balearic Islands (Spain). Cuadernos de Investigación Geográfica 42, 49-66. http://doi. org/10.18172/cig.2948.

Martín, J.L., Bethencourt, J., Cuevas-Agulló, E. 2012. Assessment of global warming on the island of Tenerife, Canary Islands (Spain). Trends in minimum, maximum and mean temperatures since 1944. Climatic Change 114, 343-355. http://doi.org/10.1007/s10584-012-0407-7.

Martínez, M.D., Serra, C., Burgueño, A., Lana, X. 2010. Time trends of daily maximum and minimum temperatures in Catalonia (NE Spain) for the period 1975-2004. International Journal of Climatology 30, 267-290. http://doi.org/10.1002/joc.1884. 
Mateos, D., Antón, M., Sánchez-Lorenzo, A., Calbó, J., Wild, M. 2013. Long-term changes in the radiative effects of aerosols and clouds in a mid-latitude region (1985-2010). Global and Planetary Change 111, 288-295. http://doi.org/10.1016/j.gloplacha.2013.10.004.

Mateos, D., Sánchez-Lorenzo, A., Antón, M., Cachorro, V.E., Calbó, J., Costa, M.J., Torres, B., Wild, M. 2014. Quantifying the respective roles of aerosols and clouds in the strong brightening since the early 2000s over the Iberian Peninsula. Journal of Geophysical Research D: Atmospheres 119, 10382-10393. http://doi.org/10.1002/2014JD022076.

Mattar, C., Sobrino, J.A., Julien, Y., Morales, L. 2011. Trends in column integrated water vapour over Europe from 1973 to 2003. International Journal of Climatology 31, 1749-1757. http:// doi.org/10.1002/joc.2186.

McVicar, T.R., Roderick, M.L., Donohue, R.J., Van Niel, T.G. 2012. Less bluster ahead? ecohydrological implications of global trends of terrestrial near-surface wind speeds. Ecohydrology 5, 381-388. http://doi.org/10.1002/eco.1298.

McVicar, T.R., Roderick, M.L., Donohue, R.J., Li, L.T., Van Niel, T.G., Thomas, A., Grieser, J., Jhajharia, D., Himri, Y., Mahowald, N.M., Mescherskaya, A.V., Kruger, A.C., Rehman, S., Dinpashoh, Y. 2012b. Global review and synthesis of trends in observed terrestrial nearsurface wind speeds: implications for evaporation. Journal of Hydrology 416-417, 182-205. http://doi.org/ 10.1016/j.jhydrol.2011.10.024.

Merino, A., Fernández-Vaquero, M., López, L., Fernández-González, S., Hermida, L., Sánchez, J.L., García-Ortega, E., Gascón, E. 2016. Large-scale patterns of daily precipitation extremes on the Iberian Peninsula. International Journal of Climatology 36, 3873-3891. http://doi. org/10.1002/joc.4601.

Moral, F.J., Paniagua, L.L., Rebollo, F.J., García-Martín, A. 2016. Spatial analysis of the annual and seasonal aridity trends in Extremadura, southwestern Spain. Theoretical and Applied Climatology. http://doi.org/10.1007/s00704-016-1939-y.

Miro, J., Estrela, M.J., Caselles, V., Olcina, J. 2015. Statistical downscaling and attribution of air temperature change patterns in the Valencia region (1948-2011). Atmospheric Research 156, 189-212. http://doi.org/10.1016/j.atmosres.2015.01.003.

Moratiel, R., Soriano, B., Centeno, A., Spano, D., Snyder, R.L. 2016. Wet-bulb, dew point, and air temperature trends in Spain. Theoretical and Applied Climatology. http://doi.org/10.1007/ s00704-016-1891-x.

Navarro-Serrano, F.M., López-Moreno, J.I. 2017. Spatio-temporal analysis of snowfall events in the Spanish Pyrenees and their relationships to atmospheric circulation. Cuadernos de Investigación Geográfica 43 (1), 233-254. http://doi.org/10.18172.cig.3042.

Peña-Angulo, D., Cortesi, N., Brunetti, M., González-Hidalgo, J.C. 2015. Spatial variability of maximum and minimum monthly temperature in Spain during 1981-2010 evaluated by correlation decay distance (CDD). Theoretical and Applied Climatology 122, 35-45. http:// doi.org/10.1007/s00704-014-1277-x.

Peña-Gallardo, M., Gámiz-Fortis, S.R., Castro-Díez, Y., Esteban-Parra, M.J. 2016. Análisis comparativo de índices de sequía en Andalucía para el periodo 1901-2012. Cuadernos de Investigación Geográfica 42 (1), 67-88. http://doi.org/10.18172/cig.2946.

Peña-Ortiz, C., Barriopedro, D., García-Herrera, R. 2015. Multidecadal variability of the summer length in Europe. Journal of Climate 28,5375-5388. http://doi.org/10.1175/JCLI-D-14-00429.1 .

Perdigao, J.C., Salgado, R., Costa, M.J., Dasari, H.P., Sanchez-Lorenzo, A. 2016. Variability and trends of downward surface global solar radiation over the Iberian Peninsula based on ERA-40 reanalysis. International Journal of Climatology 36,3917-3933.http://doi.org/10.1002/joc.4603.

Pons, M.R., San-Martín, D., Herrera, S., Gutiérrez, J.M. 2010. Snow trends in Northern Spain: Analysis and simulation with statistical downscaling methods. International Journal of Climatology 30, 1795-1806. http://doi.org/10.1002/joc.2016. 
Ramis, C., Llasat, M.C., Genovés, A., Jansá, A. 1997. The October, 1987 floods in Catalonia: synoptic and meso-scale mechanisms. Meteorological Applications 1, 337-350. http://doi. org/10.1002/met.5060010404.

Rodrigo, F.S. 2010. Changes in the probability of extreme daily precipitation observed from 1951 to 2002 in the Iberian Peninsula. International Journal of Climatology 30, 1512-1525. http:// doi.org/10.1002/joc.1987.

Rodríguez, R., Llasat, M.-C., Wheeler, D. 1999. Analysis of the Barcelona precipitation series 1850-1991. International Journal of Climatology 19, 787-801. http://doi.org/10.1002/ (SICI)1097-0088(19990615)19:7<787::AID-JOC382>3.0.CO;2-2.

Rodríguez-Puebla, C., Encinas, A.H., García-Casado, L.A., Nieto, S. 2010. Trends in warm days and cold nights over the Iberian Peninsula: Relationships to large-scale variables. Climatic Change 100, 667-684. http://doi.org/10.1007/s10584-009-9721-0.

Rodríguez-Puebla, C., Nieto, S. 2010. Trends of precipitation over the Iberian Peninsula and the North Atlantic Oscillation under climate change conditions. International Journal of Climatology 30, 1807-1815. http://doi.org/10.1002/joc.2035.

Ruíz-Sinoga, J.D., Garcia Marín, R., Martínez Murillo, J.F., Gabarrón Galeote, M.A. 2011. Precipitation dynamics in southern Spain: Trends and cycles. International Journal of Climatology 31, 2281-2289. http://doi.org/10.1002/joc.2235.

Sánchez-Lorenzo, A., Calbó, J., Brunetti, M., Deser, C. 2009. Dimming/brightening over the Iberian Peninsula: Trends in sunshine duration and cloud cover and their relations with atmospheric circulation. Journal of Geophysical Research Atmospheres 114, 8, D00D09, 38. http://doi.org/10.1029/2008JD011394.

Sánchez-Lorenzo, A., Pereira, P., López-Bustins, J.A., Lolis, C.J. 2012. Summer night-time temperature trends on the Iberian Peninsula and their connection with large-scale atmospheric circulation patterns. International Journal of Climatology 32, 1326-1335. http://doi.org/10.1002/joc.2354.

Sánchez-Lorenzo, A., Calbó, J., Wild, M. 2013. Global and diffuse solar radiation in Spain: Building a homogeneous dataset and assessing their trends. Global and Planetary Change 100, 343-352. http://doi.org/10.1016/j.gloplacha.2012.11.010.

Sánchez-Lorenzo, A., Vicente-Serrano, S.M., Wild, M., Calbó, J., Azorín-Molina, C., Peñuelas, J. 2014. Evaporation trends in Spain. Feasibility and hidden potential of Piché evaporimeter as compared to pan observations. Climate Research 61, 269-280. http://doi.org/10.3354/cr01255.

Sherwood, S., Fu, Q. 2014. A drier future? Science 343, 737-739. http://doi.org/10.1126/ science. 1247620 .

Sigró, J., Brunet, M., Domokos, P., Aguilar, E., Gilabert, A., Lister, D., Luna, Y., Mestre, A., Jones, P.D. 2015. Long-term temperature change over mainland Spain: an update to 2014 and reassessment of the Spanish daily adjusted temperature series (SDATS). In: Climate-Es 2015, 11-13 March 2015, Tarragona, Spain. http://www.climaes2015.urv.cat.

Simmons, A.J., Willett, K.M., Jones, P.D., Thorne, P.W., Dee, D.P. 2010. Low-frequency variations in surface atmospheric humidity, temperature, and precipitation: inferences from reanalyses and monthly gridded observational data sets. Journal of Geophysical Research D Atmosphere 115, D01110. http://doi.org/10.1029/2009JD012442.

Trenberth, K.E. 2015. Has there been a hiatus? Science 349, 691-692. http://doi.org/10.1126/ science.aac9225.

Turco, M., Llasat, M.C. 2011. Trends in indices of daily precipitation extremes in Catalonia (NE Spain), 1951-2003. Natural Hazards and Earth System Science 11, 3213-3226. http://doi. org/10.5194/nhess-11-3213-2011.

Valencia, J.L., Tarquis, A.M., Saá-Requejo, A., Gascó, J.M. 2012. Change of extreme rainfall indexes at Ebro River Basin. Natural Hazards and Earth System Science 12, 2127-2137. http://doi.org/10.5194/nhess-12-2127-2012. 
Vautard, R., Cattiaux, J., Yiou, P., Thepaut, J.N., Ciais, P. 2010. Northern Hemisphere atmospheric stilling partly attributed to an increase in surface roughness. Nature Geoscience 3, 756-761. http://doi.org/ 10.1038/ngeo979.

Vicente-Serrano, S. M., López-Moreno, J.I. 2006. The influence of atmospheric circulation at different spatial scales on winter drought variability through a semi-arid climatic gradient in North-east Spain. International Journal of Climatology 26, 1427-1453. http://doi. org/10.1002/joc.1387.

Vicente-Serrano, S.M. 2013. Spatial and temporal evolution of precipitation droughts in Spain in the last century. In: Adverse Weather in Spain (C. García-Legaz Martínez, F. Valero Rodríguez, Eds.). A. Madrid Vicente Ediciones. Madrid, pp. 283-296.

Vicente-Serrano, S.M., Azorín-Molina, C., Sánchez-Lorenzo, A., Morán-Tejeda, E., LorenzoLacruz, J., Revuelto, J., López-Moreno, J.I., Espejo, F. 2014. Temporal evolution of surface humidity in Spain: recent trends and possible physical mechanisms. Climate Dynamics 42, 2655-2674. http://doi.org/10.1007/s00382-013-1885-7.

Vicente-Serrano, S.M., Azorín-Molina, C., Sánchez-Lorenzo, A., Revuelto, J., López-Moreno, J.I., González-Hidalgo, J.C., Moran-Tejeda, E., Espejo, F. 2014b. Reference evapotranspiration variability and trends in Spain, 1961-2011. Global and Planetary Change 121, 26-40. http:// doi.org/ 10.1016/j.gloplacha.2014.06.005.

Vicente-Serrano, S.M., Azorín-Molina, C., Sánchez-Lorenzo, C., Revuelto, J., Morán-Tejeda, E., López-Moreno, J.I., Espejo, F. 2014c. Sensitivity of reference evapotranspiration to changes in meteorological parameters in Spain (1961-2011). Water Resources Research 50, 84588480. http://doi.org/10.1002/2014WR015427.

Vicente-Serrano, S.M., López-Moreno, J.I., Beguería, S., Lorenzo-Lacruz, J., Sánchez-Lorenzo, A, García-Ruiz, J.M., Azorín-Molina, C., Morán-Tejeda, E., Revuelto, J., Trigo, R., Coelho, F., Espejo, F. 2014d. Evidence of increasing drought severity caused by temperature rise in southern Europe. Environmental Research Letters 9, 044001. http://doi.org/10.1088/17489326/9/4/044001.

Vicente-Serrano, S.M. 2016. Foreword: Drought complexity and assessment under climate change conditions. Cuadernos de Investigación Geográfica 42 (1), 7-11. http://doi.org/10.18172/ cig.2961.

Wehner, M.F., Easterling, D.R. 2015. The global warming Hiatus's irrelevance. Science 350, 1482-1483. http://doi.org/10.1126/science.350.6267.1482-d.

Wild, M., Folini, D., Schaer, C., Loeb, N., Dutton, E.G., Koning-Langlo, G. 2013. The global energy balance from a surface perspective. Climate Dynamics 40, 3107-3134. http://doi. org/10.1007/s00382-012-1569-8.

Willett, K.M., Dunn, R.J.H., Thorne, P.W. 2014. HadISDH land surface multi-variable humidity and temperature record for climate monitoring. Climate of the Past 10,1983-2006. http://doi. org/10.5194/cp-10-1983-2014. 